\title{
Auditory Cortex Is Required for Fear Potentiation of Gap Detection
}

\author{
Aldis P. Weible, ${ }^{1}$ Christine Liu, ${ }^{2,3}$ Cristopher M. Niell, ${ }^{1,3}$ and Michael Wehr ${ }^{1,2}$ \\ ${ }^{1}$ Institute of Neuroscience, ${ }^{2}$ Department of Psychology, and ${ }^{3}$ Department of Biology, University of Oregon, Eugene, Oregon 97403
}

\begin{abstract}
Auditory cortex is necessary for the perceptual detection of brief gaps in noise, but is not necessary for many other auditory tasks such as frequency discrimination, prepulse inhibition of startle responses, or fear conditioning with pure tones. It remains unclear why auditory cortex should be necessary for some auditory tasks but not others. One possibility is that auditory cortex is causally involved in gap detection and other forms of temporal processing in order to associate meaning with temporally structured sounds. This predicts that auditory cortex should be necessary for associating meaning with gaps. To test this prediction, we developed a fear conditioning paradigm for mice based on gap detection. We found that pairing a 10 or $100 \mathrm{~ms}$ gap with an aversive stimulus caused a robust enhancement of gap detection measured $6 \mathrm{~h}$ later, which we refer to as fear potentiation of gap detection. Optogenetic suppression of auditory cortex during pairing abolished this fear potentiation, indicating that auditory cortex is critically involved in associating temporally structured sounds with emotionally salient events.
\end{abstract}

Key words: Auditory cortex; fear conditioning; gap detection; optogenetics

\section{Introduction}

A child's first words are powerful evidence that neural circuits can associate meaning with temporally structured sounds. This process involves at least two steps: the encoding of acoustic temporal structure, and associative learning of the significance of that structure. Animal models for each of these steps are now well established. Gap detection is a model for the encoding and processing of temporal structure, in which animals detect the presence of a gap in ongoing background noise. These gaps mimic voice-onset time and similar gaps within and between phonemes, which are critical cues for segmentation and discrimination of speech sounds (Lisker and Abramson, 1964, Brugge and Merzenich, 1973, Eggermont, 1999, Phillips et al., 2002, Engineer et al., 2008). Recent work in rats and mice has shown that auditory cortex is necessary for detection of brief gaps $(<50 \mathrm{~ms})$, but not longer gaps (Ison et al., 1991, Threlkeld et al., 2008, Weible et al., 2014). However, auditory cortex is not necessary for many other auditory tasks, such as prepulse inhibition (PPI) of startle responses, frequency discrimination, or fear conditioning to pure tone stimuli (Ohl et al., 1999, LeDoux, 2000, Swerdlow et al., 2001). It remains unclear why auditory cortex should be necessary for gap detection but not for many other auditory tasks. For example, neurons in the inferior colliculus (IC) precisely encode gap stimuli (Walton et al., 1997, Walton et al., 2008) and can mediate sensory-motor tasks such as PPI in the absence of auditory cortex. Why is the IC gap representation not sufficient to

Received Aug. 14, 2014; revised Sept. 11, 2014; accepted Sept. 29, 2014.

Author contributions: A.P.W. and M.W. designed research; A.P.W. and C.L. performed research; C.M.N. contributed unpublished reagents/analytic tools; A.P.W. analyzed data; A.P.W. and M.W. wrote the paper.

This work was supported by the National Institutes of Health (Grants 1R01DC011379 and 1R01EY023337).

The authors declare no competing financial interests.

Correspondence should be addressed to Michael Wehr, Institute of Neuroscience, 1254 University of Oregon, Eugene, 0R 97403; E-mail: wehr@uoregon.edu.

DOI:10.1523/JNEUROSCI.3408-14.2014

Copyright $\odot 2014$ the authors $\quad 0270-6474 / 14 / 3415437-09 \$ 15.00 / 0$ mediate gap detection when auditory cortex is inactivated? We propose that auditory cortex is causally involved in gap detection and other forms of temporal processing in order to associate meaning with temporally structured sounds, the second of the two steps mentioned above.

This proposal predicts that auditory cortex should be necessary for associating meaning with gaps. To test this prediction, we developed a temporally precise fear conditioning paradigm for mice (Zou et al., 2005 modified from Li et al., 2008 and using the PPI-based gap detection method described in Weible et al., 2014). We found that pairing a brief $10 \mathrm{~ms}$ gap with an aversive stimulus caused a subsequent enhancement of gap detection, which we refer to as fear potentiation of gap detection. We then tested whether cortical gap responses are necessary for fear potentiation of gap detection by optogenetically suppressing gap termination responses (GTRs) in auditory cortex with high temporal precision during shock pairing. We found that cortical suppression blocked learning, indicating that auditory cortex is necessary for fear potentiation of gap detection. Surprisingly, auditory cortex was also necessary for fear potentiation with long gaps $(100 \mathrm{~ms})$, even though auditory cortex is not necessary for simple detection of these long gaps. We conclude that auditory cortex is critically involved in associative learning of the emotional significance of the temporal features of sounds.

\section{Materials and Methods}

Procedures. All procedures were performed in strict accordance with the National Institutes of Health guidelines and approved by the University of Oregon Institutional Animal Care and Use Committee. All surgeries were performed using aseptic techniques.

Mice. We measured fear potentiation of gap detection in offspring from two transgenic crosses (both males and females), which provided two alternative methods of optogenetic suppression. We used two suppression methods to verify that the results were robust. First, we measured behavior in offspring $(n=66)$ of a cross between a CaMKII-tTA line (“CaMKII," 003010; The Jackson Laboratory) and a tTA-dependent 
Archaerhodopsin (Arch) line (Weible et al., 2014). In these mice, Arch (Han et al., 2011) was expressed in CaMKII ${ }^{+}$pyramidal neurons. Second, we assessed behavior in homozygotic offspring $(n=72)$ of a cross between Pvalb-IRES-Cre ("PV," 008069; The Jackson Laboratory) and CAG-ChR2-eYFP (012569; The Jackson Laboratory) lines. In these mice, ChR2 was expressed in parvalbumin-expressing $\left(\mathrm{PV}^{+}\right)$interneurons. To control for any nonoptogenetic effects of laser illumination, we collected "laser control" data from non-+/+ CaMKII mice. We also measured behavior in mice implanted only with periorbital shock electrodes (i.e., not implanted with optic fibers); these included $+/+$ and non- $+/+$ CaMKII mice and PV-ChR2 mice. We characterized the spatial extent of suppression in anesthetized mice, with 5 PV-ChR2 mice and 2 control mice not expressing ChR2. Additional electrophysiological characterization of neuronal and behavioral gap responses in PV-ChR2 mice were performed in 4 awake mice. In total, we collected data from 149 mice.

Surgery. We administered dexamethasone $(0.1 \mathrm{mg} / \mathrm{kg})$ and atropine $(0.03 \mathrm{mg} / \mathrm{kg})$ presurgically to reduce inflammation and respiratory irregularities. Surgical anesthesia was maintained with isoflurane (1.25$2.0 \%$ ). We implanted $200 \mu \mathrm{m}$ optic fibers in each hemisphere at AP -2.3 $\mathrm{mm}$ (relative to bregma), ML $4.4 \mathrm{~mm}$, and depth $0.5 \mathrm{~mm}$ below the dura (just dorsal to primary auditory cortex). Teflon-coated stainless-steel shock electrodes ( $130 \mu \mathrm{m}$ diameter bare) were inserted into the muscle immediately caudal to the eye on the left side of the head. We administered ketoprofen $(4.0 \mathrm{mg} / \mathrm{kg})$ postoperatively to minimize discomfort. Mice were housed individually after the surgery and allowed $7 \mathrm{~d}$ of postoperative recovery.

Behavioral data acquisition and stimuli. All behavioral data were collected in a sound-attenuating chamber. Sounds were delivered from a free-field speaker directly facing the animal. The speaker was calibrated to within $\pm 1 \mathrm{~dB}$ using a Brüel and Kjær 4939 1/4-inch microphone positioned where the ear would be but without the animal present. Mice were loosely restrained in a plastic tube $(35 \mathrm{~mm}$ inner diameter, $1.5 \mathrm{~mm}$ wall thickness) affixed to a flat base. The head was fixed in position. The tube was perforated ( $\sim 3 \mathrm{~mm}$ diameter) to allow effective transmission of sound, with no more than $5 \mathrm{~dB}$ attenuation. An open slot along the top provided access to the implanted fibers and shock electrodes. To measure the startle response, the tube rested on a piezo transducer. Movement signals from the piezo transducer were amplified and digitized at $10 \mathrm{kHz}$.

We measured gap detection using a variant of PPI in which a gap that precedes a startle stimulus reduces the magnitude of the startle response. Acoustic stimuli were embedded in continuous background white noise ( $80 \mathrm{~dB}$ SPL). Startle stimuli ( $25 \mathrm{~ms}$ white noise bursts, $100 \mathrm{~dB}$ SPL) were separated by a random intertrial interval (ITI) of $15 \pm 5 \mathrm{~s}$. Silent gaps in the continuous background noise preceded the startle stimulus, separated by a $50 \mathrm{~ms}$ interval between the end of the gap and the onset of the startle stimulus (ISI). The basic behavioral protocol (Fig. 1) included three sessions with 20 trials per session. During the first session ("preconditioning"), we measured baseline gap detection. Generally, a single gap duration of $10 \mathrm{~ms}$ was used. In this and all of the following gap detection protocols, we included 20 randomly interleaved presentations of the startle stimulus in isolation, which we refer to as a " $0 \mathrm{~ms}$ " gap. We then normalized all startle responses (within each session) to this measure of "pure" startle amplitudes. During the second session ("conditioning"), presentations of the $10 \mathrm{~ms}$ gap (the conditioned stimulus or CS) were immediately followed by a mild, $\sim 6.0 \mu \mathrm{A}$ periorbital shock, which consisted of a $50 \mathrm{~ms}$ train of $1 \mathrm{~ms}$ pulses at $500 \mathrm{~Hz}$ (the unconditioned stimulus or US). Because conditioning sessions did not include a " $0 \mathrm{~ms}$ " gap condition, we used a $30 \pm 10 \mathrm{~s}$ ITI so that the average interval between gap presentations matched that of the gap detection sessions. No acoustic startle stimulus was presented during the conditioning session. The third session ("postconditioning") was performed $6 \mathrm{~h}$ later and was identical to the preconditioning session.

To test the specificity of fear potentiation to gap duration, we performed two follow-up experiments. In these experiments, we assessed gap detection for multiple gap durations $(2,5,10,15,20$, and $25 \mathrm{~ms})$. In the first experiment, the conditioning session included only the $10 \mathrm{~ms}$ gap paired with the shock. In the second experiment, the conditioning session included all gap durations with only the $10 \mathrm{~ms}$ gap paired with the shock.
A

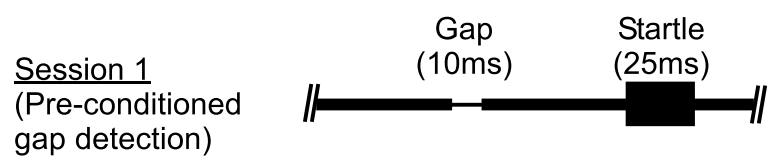

B

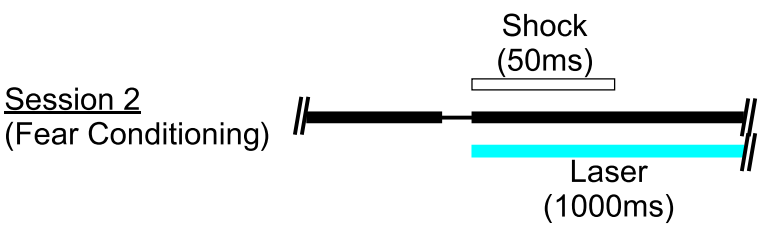

C

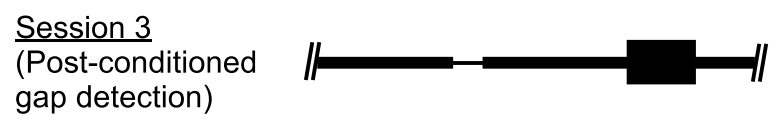

Figure 1. Gap detection measured before and after pairing of the gap and periorbital shock. $A$, We first measured gap detection in Session 1 . A 10 ms gap was embedded in continuous $80 \mathrm{~dB}$ white noise, terminating $50 \mathrm{~ms}$ before the onset of a startle stimulus ( $25 \mathrm{~ms} 100 \mathrm{~dB}$ white noise burst). Alternating trials consisted of the startle stimulus alone (without a gap). The presence of the gap attenuated the magnitude of the startle response compared with trials without a gap. Therefore, gap detection is measured as a reduction in startle response. $\boldsymbol{B}$, During conditioning (Session 2), the gap was immediately followed by a 50 ms periorbital shock (25 $1 \mathrm{~ms}, 6 \mu \mathrm{A}$ current pulses at $500 \mathrm{~Hz}$ ). C, Six hours later, gap detection was reassessed (Session 3). In cortical suppression experiments, shock onset coincided with laser illumination of auditory cortex (200 or $300 \mathrm{~mW} / \mathrm{mm}^{2}$ at the fiber tip, $1000 \mathrm{~ms}$ duration).

We compared gap-shock pairing with two control conditions performed in separate groups of mice. In the first group ("Pseudo"), the same number of gaps and shocks were presented, but they were explicitly unpaired, alternating with a $15 \pm 5 \mathrm{~s}$ ITI in a pseudorandomized manner. In the second group ("CS-Only"), only the gap (CS) was presented during the conditioning session. In a final variation of the protocol, we used $100 \mathrm{~ms}$ gaps during both gap detection and conditioning sessions.

We used a $532 \mathrm{~nm}$ wavelength "green" laser at an intensity of 300 $\mathrm{mW} / \mathrm{mm}^{2}$ at the fiber tip (i.e., $9.5 \mathrm{~mW}$ of total power through each 200 $\mu \mathrm{m}$ fiber) to suppress excitatory cortical activity in CaMKII-Arch mice. At this intensity, the spread of suppression is limited to auditory cortex in CaMKII-Arch mice (Weible et al., 2014). In PV-ChR2 mice, we used a $445 \mathrm{~nm}$ wavelength "blue" laser at intensities of $200 \mathrm{~mW} / \mathrm{mm}^{2}(6.3 \mathrm{~mW}$ total power) and $300 \mathrm{~mW} / \mathrm{mm}^{2}$ (9.5 $\mathrm{mW}$ total power) to activate ChR2. The spatial extent of inactivation at these intensities is reported below (see Fig. 5). During conditioning, laser onset coincided with shock onset (and gap offset) and extended for $1000 \mathrm{~ms}$. We chose the $1000 \mathrm{~ms}$ duration to ensure that we suppressed cortical activity associated with both gap and shock presentations.

Behavioral analyses. We quantified startle amplitudes by calculating the area of the rectified startle response signal within a $100 \mathrm{~ms}$ window after startle stimulus onset. We quantified baseline movement during the $100 \mathrm{~ms}$ interval preceding the gap in the same way. We excluded trials on which baseline movement exceeded that of the startle response due to spurious movements. For each mouse, we normalized startles to the mean pure startle response. We excluded mice from analysis $(n=12)$ if they did not show significant gap detection for any session.

We used the paired $t$ test to assess within-group changes with conditioning. "Learning" was defined as a significant increase in gap detection (i.e., a decrease in startle responses) after conditioning. We used unpaired $t$ tests for between-groups comparisons. We used ANOVAs for group comparisons involving multiple gap durations. To determine whether conditioning changed startle sensitivity, we compared the raw (rectified, but non-normalized) pure startle response before and after conditioning. To test for any differences in shock sensitivity across groups of mice, we compared the mean amplitude of the shock-elicited startle (UR) between groups. We applied a Bonferroni correction for comparisons ( $t$ tests or ANOVAs) involving more than two groups. 

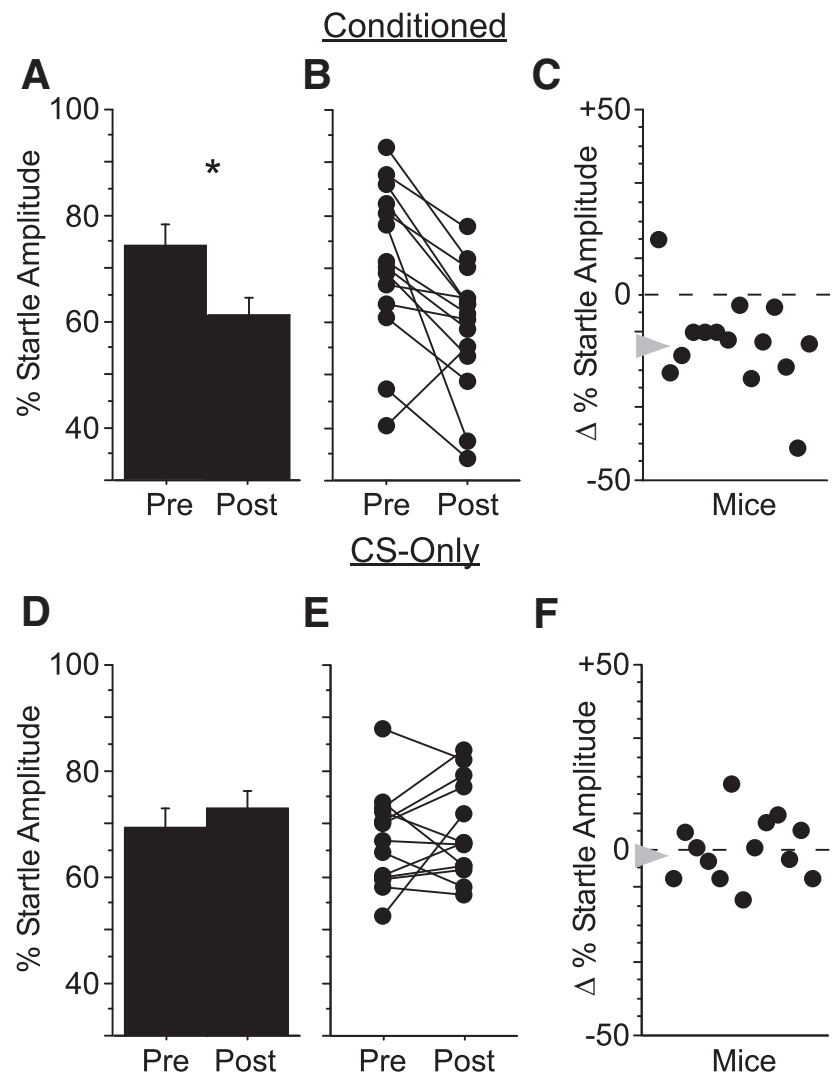

E

$\mathbf{F}$
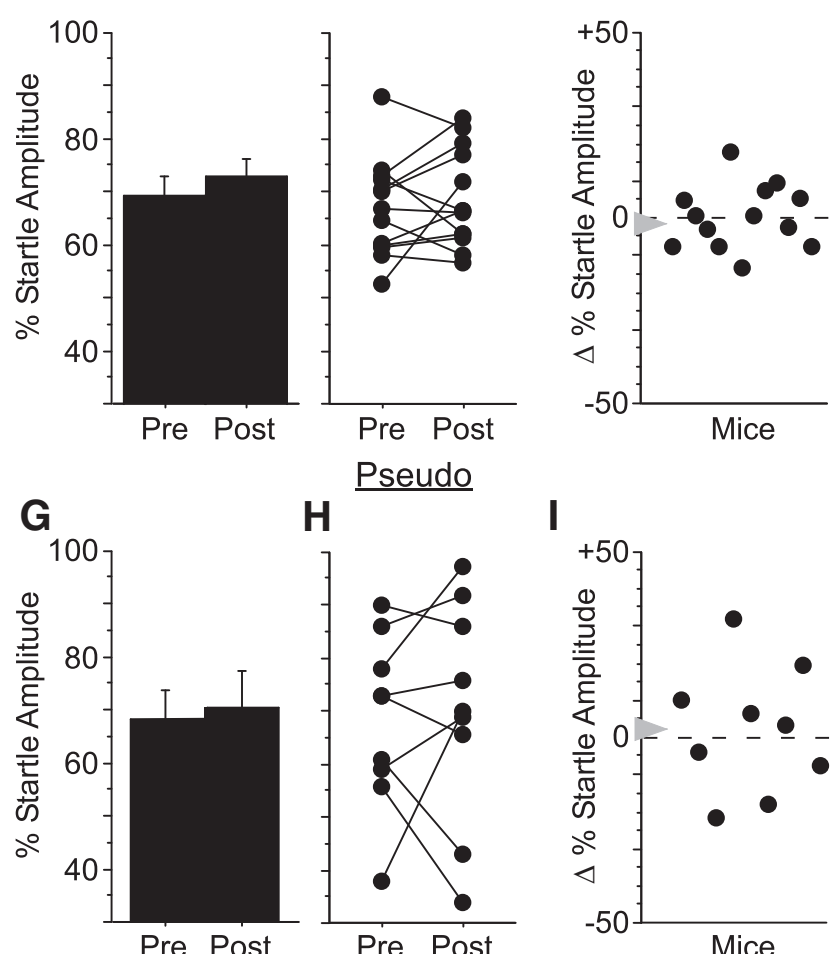

H

Pseudo
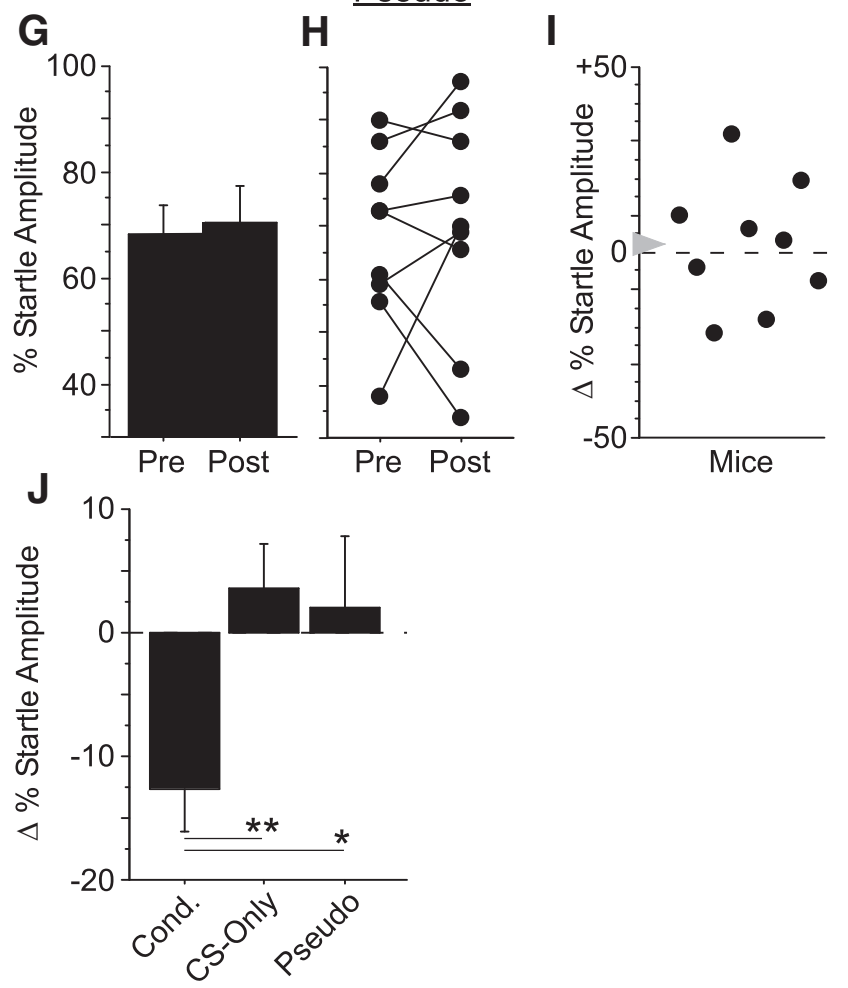

Figure 2. Gap-shock pairing enhances gap detection. We measured gap detection before conditioning (Pre) and again $6 \mathrm{~h}$ after conditioning (Post) in three separate groups of mice. $\boldsymbol{A}$, One group of mice (Conditioned; $n=14$ ) was presented with paired presentations of the $10 \mathrm{~ms}$ gap (CS) and a periorbital shock (US). These mice showed a significant increase in gap detection after conditioning. $\boldsymbol{B}$, This effect was highly consistent across animals. $\boldsymbol{C}$, Net change in percentage startle amplitude after conditioning for each animal; gray arrow indicates the mean. $\boldsymbol{D}-\boldsymbol{F}$, A second group of mice (CS-Only; $n=13$ ) was presented with the gap-CS only (no shocks were presented). There was no change in gap detection after conditioning. G-I, A third
Spatial extent of suppression in $P V-C h R 2$ mice. We previously verified the efficacy of suppressing auditory cortex in CaMKII-Arch mice (Weible et al., 2014). Here, we used multiunit recordings in anesthetized mice to characterize the spatial extent of cortical suppression in PVChR2 mice using methods similar to those described previously (Weible et al., 2014). Briefly, mice were anesthetized (ketamine $120 \mathrm{mg} / \mathrm{kg}$, medetomidine $0.24 \mathrm{mg} / \mathrm{kg}$, and acepromazine $3.0 \mathrm{mg} / \mathrm{kg}$ ), positioned in a custom head restraint, and maintained at $37^{\circ} \mathrm{C}$. A craniotomy $(\sim 3 \times 2$ $\mathrm{mm}$ ) was made over auditory cortex and the dura was left intact. A single $200 \mu \mathrm{m}$ fiber was positioned in contact with the cortical surface and cemented in place. For these experiments, we positioned a sharp tungsten microelectrode (2-5 M $\Omega$ ) immediately beside and approximately parallel to the optic fiber. Multiunit responses to $70 \mathrm{~dB}, 25 \mathrm{~ms}$ white noise bursts were recorded at $50 \mu \mathrm{m}$ depth increments beginning $250 \mu \mathrm{m}$ beneath the cortical surface. Multiple penetrations were made in each animal. A $200 \mathrm{~ms}$ laser pulse beginning $100 \mathrm{~ms}$ before noise onset was presented on alternating trials. Spikes were extracted by high-pass filtering and thresholding at $\geq 3 \mathrm{SD}$ of the extracellular voltage. At each depth, we compared spike counts in $75 \mathrm{~ms}$ windows before and after sound onset and a $75 \mathrm{~ms}$ window preceding laser onset. Activation of $\mathrm{PV}^{+}$cells strongly suppressed spiking of presumed excitatory neurons. However, at some superficial recording sites, light evoked robust multiunit activity, presumably due to direct activation of $\mathrm{PV}^{+}$cells. We excluded such sites from analysis in characterizing the spatial extent of suppression. Specifically, we excluded sites exhibiting a significant increase in spiking activity after laser onset but before sound onset (paired $t$ test). For the remaining sites, we calculated the ratio of sound-evoked spiking activity with and without laser illumination. We binned these values in $250 \mu \mathrm{m}$ increments and compared PVxChR2 mice (using either 200 or $300 \mathrm{~mW} /$ $\mathrm{mm}^{2}$ ) with non-PV-ChR2 control mice (unpaired $t$ tests).

Single neuron recording. We also verified the efficacy of suppressing auditory cortex in PV-ChR2 mice on gap detection and production of the GTR. We implanted a single optical fiber in the right hemisphere and an eight-tetrode "optrode" array (Zhang et al., 2009) in the left hemisphere. The array consisted of a $200 \mu \mathrm{m}$ optic fiber and 8 tetrodes passed through a length of 23 gauge stainless steel hypodermic tubing. Tetrodes were made of $18 \mu \mathrm{m}$ ( $25 \mu \mathrm{m}$ coated) tungsten wire (California Fine Wire). The entire array was mounted on a custom microdrive. Tetrode data were acquired with 32-channel RHD2000 hardware (Intan Technologies) and Open Ephys software (http://open-ephys.org). We used a minimum threshold of $50 \mu \mathrm{V}$ for collection of spiking activity. We simultaneously recorded behavior and neural activity during gap detection. We applied laser stimulation during the $50 \mathrm{~ms}$ postgap ISI on alternating trials.

We isolated the spiking activity of individual neurons offline using the open source spike sorting software packages Simpleclust (http://jvoigts. scripts.mit.edu/blog/simpleclust-manual-spike-sorting-in-matlab) and MClust (http://redishlab.neuroscience.umn.edu/MClust/MClust.html). Data were analyzed only from well isolated cells, as described previously (Weible et al., 2012). We defined a significant GTR as a significant increase in spiking activity during the $50 \mathrm{~ms}$ postgap interval compared with the $50 \mathrm{~ms}$ interval immediately preceding the gap (paired $t$ test). We then compared GTRs for laser "on" and laser "off" trials to determine effects of cortical suppression on the GTR (unpaired $t$ test).

Histology. Histology was performed on all mice implanted with optic fibers. Brains were sectioned coronally at $100 \mu \mathrm{m}$. We verified fluorophore expression, placement of optic fibers and placement of the recording tetrodes in auditory cortex using the structure of the hippocampus and the rhinal fissure as rostrocaudal and dorsoventral landmarks.

$\leftarrow$

group of mice (Pseudo; $n=9$ ) received explicitly unpaired presentations of the gap-CS and shock-US. No change in mean gap detection was observed in Pseudoconditioned mice $(\boldsymbol{G})$, but variability between mice $(\boldsymbol{H}, \boldsymbol{I})$ was significantly greater than that seen in CS-Only mice $(\boldsymbol{C}) . \boldsymbol{J}$, Mean change in startle amplitude after conditioning was significantly greater for Conditioned mice compared with CS-Only or Pseudo mice. ${ }^{*} p<0.05 ;{ }^{* *} p<0.01$. 
Table 1. Summary of results

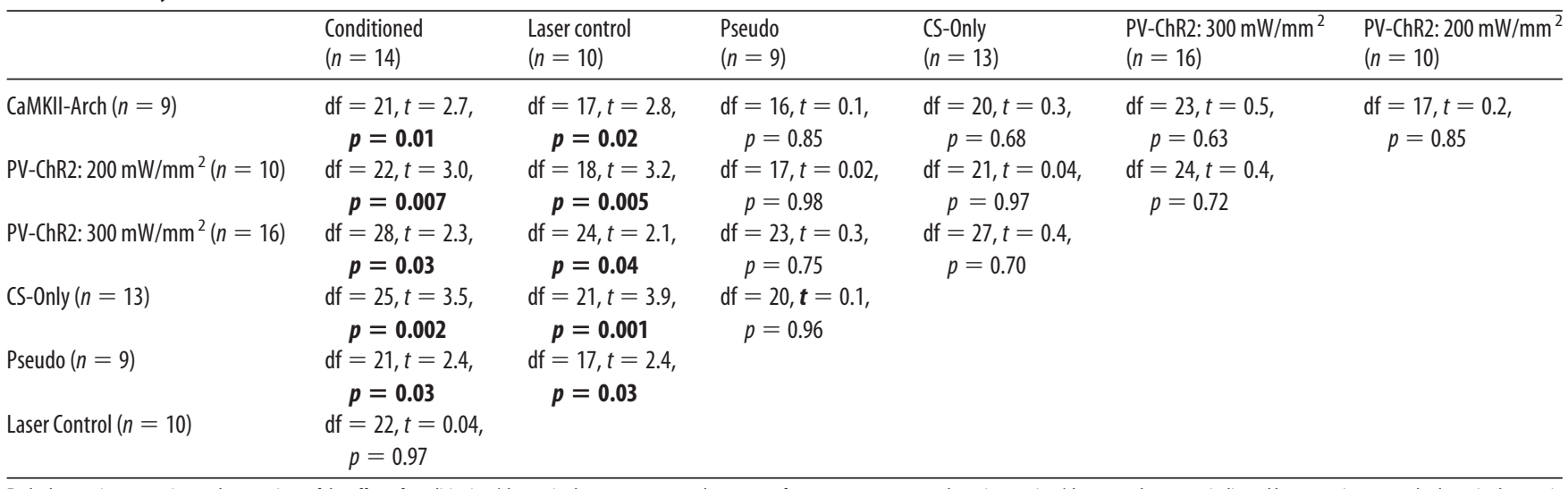

Each element is an experimental comparison of the effect of conditioning (change in the percentage startle response from pregap to postgap detection sessions) between the groups indicated by respective row and column in the matrix. Significant differences between groups are in bold (unpaired $t$ test).

\section{Results}

Fear potentiation of gap detection

We first set out to establish a temporally precise fear conditioning paradigm in mice based on a gap detection task (Fig. 1). We measured gap detection using a variant of prepulse inhibition in which a silent $10 \mathrm{~ms}$ gap is inserted into continuous background noise. The gap acts as a cue that reduces the startle response evoked by a subsequent loud noise burst (Ison and Pinckney, 1983). We first measured gap detection in a baseline session (Fig. $1 A)$ and then paired the gap with a mild periorbital shock $(20$ repetitions; Fig. $1 B$ ). When we remeasured gap detection $6 \mathrm{~h}$ later (Fig. $1 C$ ), we found it to be significantly enhanced (Fig. $2 A ; \mathrm{df}=$ $13, t=3.8, p=0.002)$. In other words, the gap caused a greater reduction of startle responses after fear conditioning.

This fear potentiation of gap detection was highly reliable across animals, with 13/14 mice showing a significant effect (Fig. $2 B)$. Fear potentiation was also learning specific. Mice presented only with gaps during the conditioning session (CS-Only group, i.e., no shocks; $n=13$ mice) showed no change in group behavior $6 \mathrm{~h}$ later (Fig. 2D). Explicitly unpaired presentations of gaps and shocks also did not elicit a group effect (Pseudo group; $n=9$ mice; Fig. 2G). Accordingly, fear-conditioned mice exhibited a greater change in gap detection than either CS-Only or Pseudo mice (Fig. 2J, Table 1). These results indicate that fear conditioning with brief $10 \mathrm{~ms}$ gaps markedly enhanced gap detection and suggest that fear conditioning conferred emotional significance to the gap and thereby increased gap salience.

When gaps and shocks were explicitly unpaired (Pseudo), there was no net effect on gap detection, but individual mice did show increases or decreases in gap detection (Fig. $2 \mathrm{H}, \mathrm{I}$ ). As a result, the variance in effect size across Pseudo mice was significantly greater than for CS-Only mice (cf. Fig. 2 I, F; equality of variance $F$ test, $p=0.04$ ). Variance in effect size across Conditioned mice was no different from CS-Only mice (cf. Fig. 2C,F; $p=0.20)$. This indicates that unpaired shocks affected behavior even when no CS-US association could be made. This greater variance could reflect arousal or contextual effects.

\section{Cortical involvement in fear potentiation of gap detection}

We next tested whether fear potentiation of gap detection was cortex dependent. We used two different optogenetic approaches to suppress auditory cortex for $1000 \mathrm{~ms}$ immediately after each gap, overlapping with the shock, during the conditioning session. For both approaches, we implanted chronic bilateral optic fibers over auditory cortex (Fig. 3). In the first approach, we directly

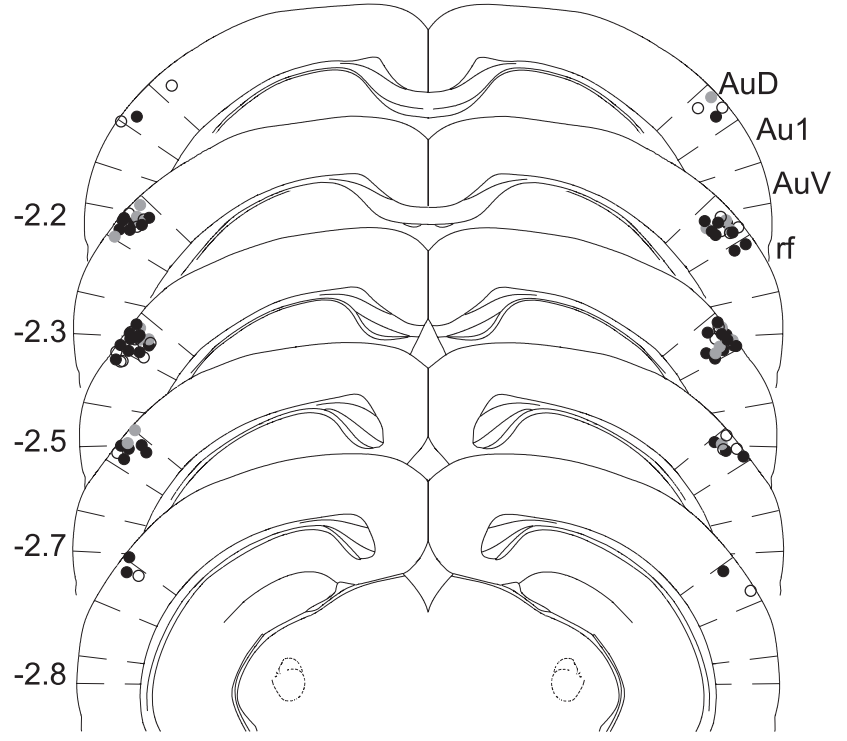

Figure 3. Optic fibers were consistently positioned in dorsal auditory cortex. All fiber placements were verified upon completion of behavioral data collection and are shown on the closest coronal section from The Mouse Brain (Paxinos and Franklin, 2001) by comparison with proximal landmarks such as the hippocampus. The distribution of fiber placements in PV-ChR2 mice (filled black circles), CaMKII-Arch mice (filled gray circles), and Laser Control mice (open circles) were overlapping and restricted predominantly to the dorsal auditory cortex (AuD) from 2.2 to $2.8 \mathrm{~mm}$ posterior to bregma. This fiber placement thereby illuminated primary auditory cortex (Au1) from above. AuV, Ventral auditory cortex; rf, rhinal fissure.

suppressed pyramidal neurons using green light in CaMKII-Arch mice. We previously demonstrated that this method effectively suppresses both GTRs in auditory cortex and behavioral gap detection (Weible et al., 2014). When we suppressed auditory cortex during gap-shock pairing, fear potentiation of gap detection was abolished (Fig. $4 A-C, n=9$ mice). Variance across mice did not differ significantly from that seen with CS-Only mice, although a trend toward increased variance was evident (Fig. $4 C, p=0.10$ ).

In the second approach, we indirectly suppressed cortical activity by activating ChR2 in PV-expressing inhibitory interneurons. We previously characterized expression specificity in this line $(97 \%)$ and demonstrated that blue light effectively activates $\mathrm{PV}^{+}$cells in anesthetized mice (Moore and Wehr, 2013). To characterize the spatial extent of cortical suppression in these mice, we used multiunit recordings of sound-evoked cortical spiking activity in anesthetized mice and compared two different 


\section{CaMKII-Arch}

A

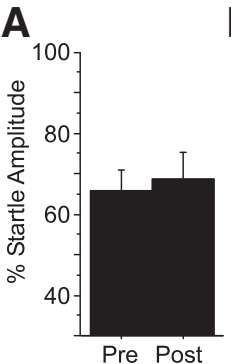

B
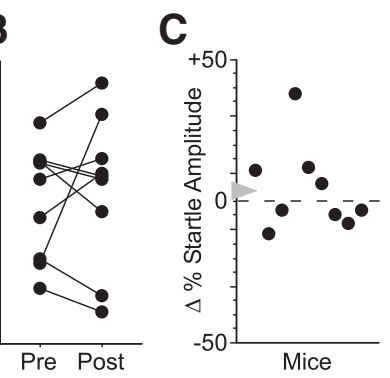

PV-ChR2: $200 \mathrm{~mW} / \mathrm{mm}^{2}$
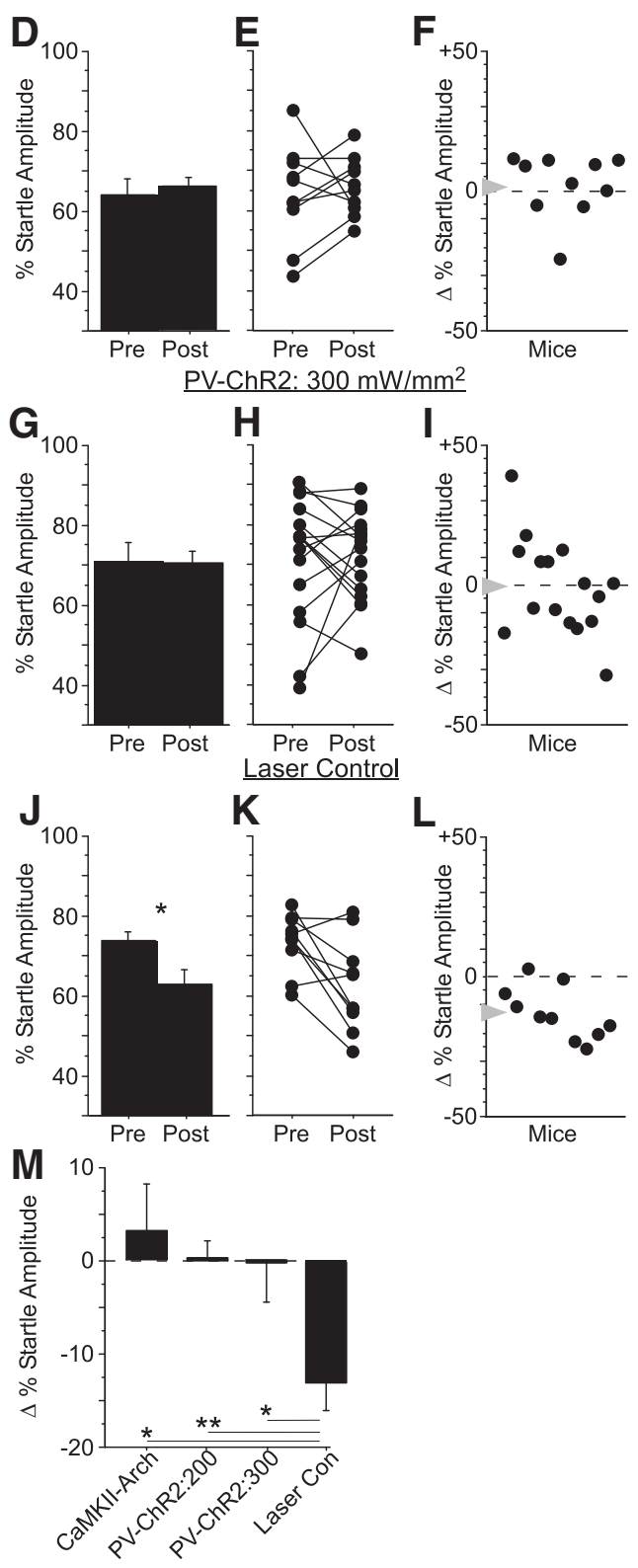

Figure 4. Cortical suppression blocked fear potentiation of gap detection. We measured gap detection before conditioning (Pre) and again $6 \mathrm{~h}$ after conditioning (Post) in four separate groups of mice. Cortical suppression was performed during shock pairing (Session 2) either directly by activating Arch in CaMKII-expressing pyramidal neurons (CaMKII-Arch) or indirectly by activating parvalbumin-expressing interneurons with Channelrhodopsin (PV-ChR2). $\boldsymbol{A}-\boldsymbol{C}$, In CaMKII-Arch mice $(n=9)$, cortical suppression with a laser intensity of $300 \mathrm{~mW} / \mathrm{mm}^{2}$ (measured at the $200 \mu \mathrm{m}$ fiber tip) blocked mean changes in startle amplitude after conditioning. In PV-ChR2 mice, cortical suppression at intensities of $200 \mathrm{~mW} / \mathrm{mm}^{2}(n=10 ; \boldsymbol{D}-\boldsymbol{F})$ and 300 $\mathrm{mW} / \mathrm{mm}^{2}(n=16 ; \boldsymbol{G} \boldsymbol{I})$ also blocked mean changes in startle amplitude after conditioning. laser powers. Significant suppression (relative to control mice) extended to $1500 \mu \mathrm{m}$ at $200 \mathrm{~mW} / \mathrm{mm}^{2}$ and extended to $1750 \mu \mathrm{m}$ at $300 \mathrm{~mW} / \mathrm{mm}^{2}$ (Fig. 5A). In summary, PV-ChR2 suppression spread further than CaMKII-Arch suppression for a given intensity such that the spatial extent of suppression for $200 \mathrm{~mW} / \mathrm{mm}^{2}$ in PV-ChR2 mice $(1500 \mu \mathrm{m})$ was the same as that for $300 \mathrm{~mW} /$ $\mathrm{mm}^{2}$ in CaMKII-Arch mice (Weible et al., 2014).

Both intensities were sufficient to produce significant suppression of sound-evoked activity throughout much of primary auditory cortex and adjacent auditory cortical fields (Fig. 5A,B). As with CaMKII-Arch mice, suppression of auditory cortex by PV activation significantly reduced behavioral gap detection (i.e., increased startle amplitudes; Fig. $5 C$; 4 mice, 12 sessions; $\mathrm{df}=11$, $t=-6.86, p<0.0001)$. To confirm that our chronically implanted fibers reliably activated $\mathrm{PV}^{+}$cells in behaving mice, we used chronic tetrodes to record from identified $\mathrm{PV}^{+}$interneurons based on their reliable short-latency responses to light. $\mathrm{PV}^{+}$cells were reliably activated throughout $50 \mathrm{~ms}$ illumination (Fig. 5D). Activating $\mathrm{PV}^{+}$cells robustly suppressed non-PV (presumably excitatory) neurons. Figure $5 E$ shows a population histogram of GTRs from 101 non-PV cells; 43 of these cells showed a significant GTR and illumination significantly reduced GTR amplitude in 37/43 of these cells. Therefore, the PV-ChR2 method effectively suppresses both auditory cortical GTRs and behavioral gap detection.

As with CaMKII-Arch mice, suppression of auditory cortex by PV activation during gap-shock pairing abolished fear potentiation of gap detection (Fig. $4 D, G ; n=10$ mice and $n=16$ mice, respectively). At the higher intensity, variability across mice was significantly greater than that of CS-Only mice (Fig. $4 I, p=0.02$ ). This suggests that, at the higher intensity, PV-ChR2 mice behaved similarly to Pseudo mice, for which gap and shock were explicitly unpaired and no CS-US association could be made. As with the CaMKII-Arch mice, variability across PV-ChR2 mice undergoing suppression with $200 \mathrm{~mW} / \mathrm{mm}^{2}$ was not significantly different from CS-Only mice (Fig. $4 F$ ).

Suppression of auditory cortex caused a specific disruption of fear potentiation rather than any nonspecific effect on behavior, as shown by several lines of evidence. First, laser presentations alone had no effect on learning. Mice implanted with fibers but not expressing Arch or ChR2 ("Laser Control," $n=10$ mice) demonstrated fear potentiation almost identical to that seen in Conditioned mice despite laser pulses during the conditioning session $(\mathrm{df}=9, t=$ $4.3, p=0.002$; Fig. $4 J$ ). The change in gap detection in Laser Control mice was indistinguishable from that of Conditioned mice (12.9 \pm $3.0 \%$ SE and $12.7 \pm 3.3 \%$ SE, respectively; Fig. $4 M$, Table 1). These results exclude any nonspecific effects of laser illumination (e.g., acting as a distractor during learning or somehow otherwise affecting the brain). Second, cortical suppression had no effect on shockelicited startle responses (UR amplitudes), indicating that the effects of cortical suppression cannot be explained by changes in shock sensitivity (Table 2). Third, pure (i.e., no gap) startle amplitudes did not differ between groups nor did the change in pure startle amplitudes after conditioning. This indicates that the observed effects did not result from any changes in startle sensitivity or from normalization of startle amplitudes (Table 2). Finally, variability in the effects of suppression across animals was unrelated to histologically verified fiber placement.

$\leftarrow$

$J-L$, Laser trials in mice not expressing Arch or ChR2 (Laser Control) showed normal fear potentiation after conditioning, indicating that the laser alone did not disrupt learning. $\boldsymbol{M}$, Gap detection in Laser Control mice was significantly greater than in CaMKII-Arch and both groups of PV-ChR2 mice. ${ }^{*} p<0.05 ;{ }^{* *} p<0.01$ 


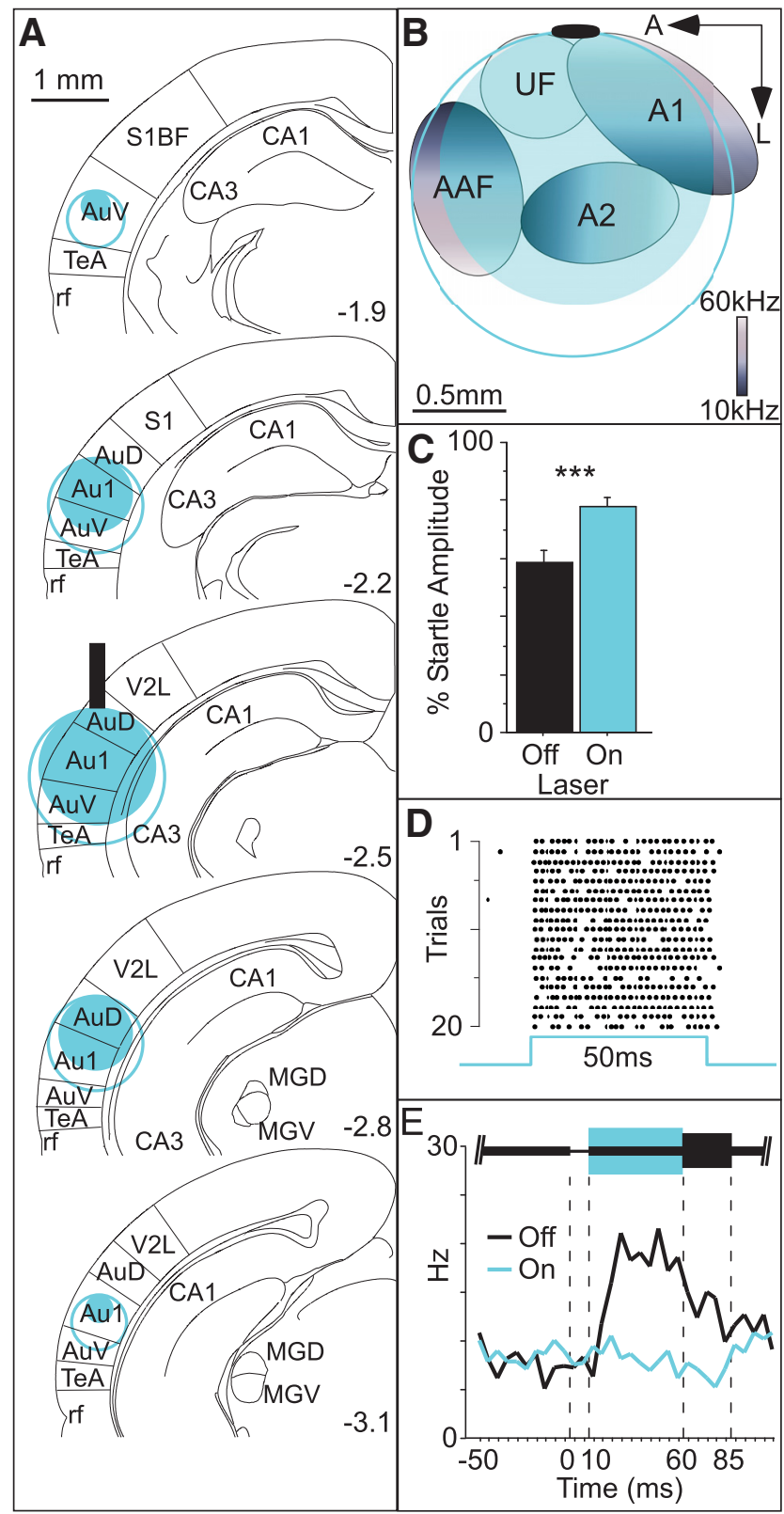

Figure 5. Optogenetic activation of $\mathrm{PV}^{+}$interneurons suppressed sound-evoked activity throughout auditory cortex and significantly reduced behavioral gap detection and neuronal GTRs. We assessed the spatial extent of PV-ChR2 suppression by recording multiunit responses to white noise bursts at depths ranging from 250 to $2000 \mu \mathrm{m}$ below the fiber (fiber indicated by vertical black bar). $\boldsymbol{A}$, Significant suppression of white noise responses was not seen beyond $1500 \mu \mathrm{m}$ with an intensity of $200 \mathrm{~mW} / \mathrm{mm}^{2}$ (solid blue disk) and not beyond $1750 \mu \mathrm{m}$ with an intensity of $300 \mathrm{~mW} / \mathrm{mm}^{2}$ (open blue circle). Using these data and assuming spherical illumination, we estimated the spatial extent of suppression rostral and caudal to the fiber from 1.9 to $3.1 \mathrm{~mm}$ posterior to bregma. $\boldsymbol{B}$, Estimated spatial extent of suppression across the cortical surface superimposed on stereotaxically coregistered tonotopic fields mapped in a separate animal. Tonotopic field boundaries follow the convention in Issa et al., 2014. Black oval indicates average fiber tip location. C, In separate animals, we simultaneously recorded behavioral gap detection and single neuron spiking activity in auditory cortex while illuminating the cortex during the $50 \mathrm{~ms}$ postgap interval $\left(445 \mathrm{~nm}, 300 \mathrm{~mW} / \mathrm{mm}^{2}\right)$. Illumination significantly reduced gap detection (i.e., increased startle amplitudes; 4 mice, 12 sessions). D, of 110 cells analyzed, 9 were identified as $\mathrm{PV}^{+}$interneurons based on the robust and reliable short-latency spiking responses to illumination, as illustrated by an example $\mathrm{PV}^{+}$neuron. $\boldsymbol{E}$, Population average peristimulus time histogram of the remaining 101 cells. Note the robust GTR after the gap (black line), which is abolished by $\mathrm{PV}^{+}$activation (blue line). ${ }^{* *} p<0.0001$. Au1, Primary auditory cortex (Au1, AuD, and AuV were defined by atlas boundaries); AuD, dorsal auditory cortex; AuV, ventral auditory cortex; $C A 1$ and $C A 3$, cell fields of the hippocampus; $M G D$, medial geniculate nucleus, dorsal; MGV, medial geniculate nucleus, ventral; rf, rhinal fissure; S1, primary
Table 2. Unconditioned response and Gap0 startle amplitudes

\begin{tabular}{llll}
\hline & UR amplitude & $\begin{array}{l}\text { Postconditioning gap 0 ms } \\
\text { startle amplitude }\end{array}$ & $\begin{array}{l}\Delta \text { Gap 0 ms startle } \\
\text { amplitude }\end{array}$ \\
\hline Conditioned & $28.7 \pm 6.6$ & $15.9 \pm 2.8$ & $-1.08 \pm 2.1$ \\
CS-Only & n.a. & $19.3 \pm 4.5$ & $-9.31 \pm 4.9$ \\
Pseudo & $25.6 \pm 7.7$ & $21.8 \pm 3.6$ & $3.12 \pm 2.4$ \\
CaMKII-Arch & $19.0 \pm 4.9$ & $12.5 \pm 2.9$ & $0.02 \pm 1.2$ \\
PV-ChR2 & $25.7 \pm 7.1$ & $20.8 \pm 3.6$ & $0.81 \pm 3.1$ \\
Laser Control & $17.4 \pm 5.1$ & $12.4 \pm 2.3$ & $0.43 \pm 1.8$ \\
\hline
\end{tabular}

Cortical suppression with CaMKII-Arch or PV-ChR2 had no effect on UR amplitudes. Pure (Gap0) startle amplitudes did not differ between groups, nor did the change in pure startle amplitudes ( $\Delta \mathrm{Gap} 0 \mathrm{~ms}$ ) after conditioning.

\section{Freezing behavior after fear potentiation}

In conventional fear conditioning paradigms, animals typically freeze in response to the CS after conditioning (LeDoux, 2000). We wondered whether mice in our task showed any evidence of freezing that was independent of startle responses. To test this, we retrospectively measured movement signals during the brief $50 \mathrm{~ms}$ interval after gap offset but before startle onset (note that any possible freezing beyond this window was obscured by startle responses). No individual group showed a change in movement after conditioning. However, when we combined the Conditioned and Laser Control groups (which both showed robust fear potentiation of gap detection), we found that conditioning produced a small but significant reduction in movement consistent with freezing $(\mathrm{df}=22, t=2.4$, $p=0.026)$. In contrast, conditioning had no effect on movement when CaMKII-Arch and PV-ChR2 groups were combined, suggesting that cortical suppression blocked the development of freezing.

\section{Generalization of fear potentiation}

These results indicate that pairing a $10 \mathrm{~ms}$ gap with shock produces fear potentiation of the detection of 10 ms gaps. We wondered whether this fear potentiation was specific to the $10 \mathrm{~ms}$ gap or if it would generalize to other gap durations. To test this, we measured gap detection for multiple gap durations $(0,2,5,10,15,20$, and 25 $\mathrm{ms}$ ) before and after the conditioning session. We used two types of conditioning. The first group was presented only with $10 \mathrm{~ms}$ gaps, which were paired with shock (no other gap durations were presented during conditioning). In the second group (differential conditioning), we presented all gap durations during conditioning, but only $10 \mathrm{~ms}$ gaps were paired with the shock. We expected that, if fear potentiation is stimulus specific, then either protocol would result in a selective enhancement of $10 \mathrm{~ms}$ gap detection after conditioning. Instead, although we found that both conditioning protocols produced significant fear potentiation, neither produced effects specific to the $10 \mathrm{~ms}$ gap (Fig. $6 A, 10 \mathrm{~ms}$ only: main effect $F_{(1,16)}=5.3, p=$ 0.036 ; Fig. $6 B$, all gaps: interaction $\left.F_{(6,96)}=2.3, p=0.041\right)$. A separate group of pseudoconditioned mice (shocks unpaired with any gap duration) showed no learning-related changes in behavior (Fig. $6 C$ ). The effects elicited by the two conditioning protocols did not differ significantly (Fig. $6 D$ ) and both protocols elicited greater gap detection compared with Pseudo mice $\left(F_{(2,23)}=6.9, p=0.012\right.$, Bonferroni corrected; Fig. 6D).

\section{Cortical involvement at long gap durations}

Auditory cortex is required for the detection of brief $(10 \mathrm{~ms})$ gaps (Ison et al., 1991, Threlkeld et al., 2008, Weible et al., 2014) and,

$\leftarrow$

somatosensory cortex; $\mathrm{S} 1 \mathrm{BF}$, primary somatosensory cortex, barrel field; TeA, temporal association cortex; V2L, secondary visual cortex, lateral area; $A 1$, primary auditory cortex $(A 1, A 2, A A F$, and UF were defined by tonotopic mapping); A2, secondary auditory cortex; AAF, anterior auditory field; UF, ultrasonic field. 

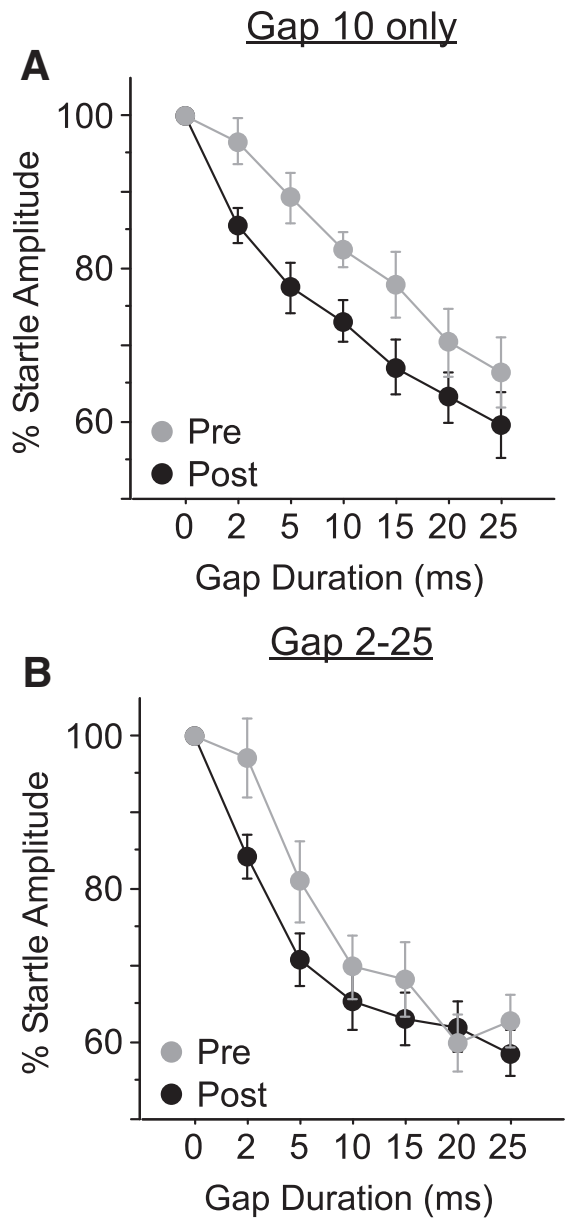
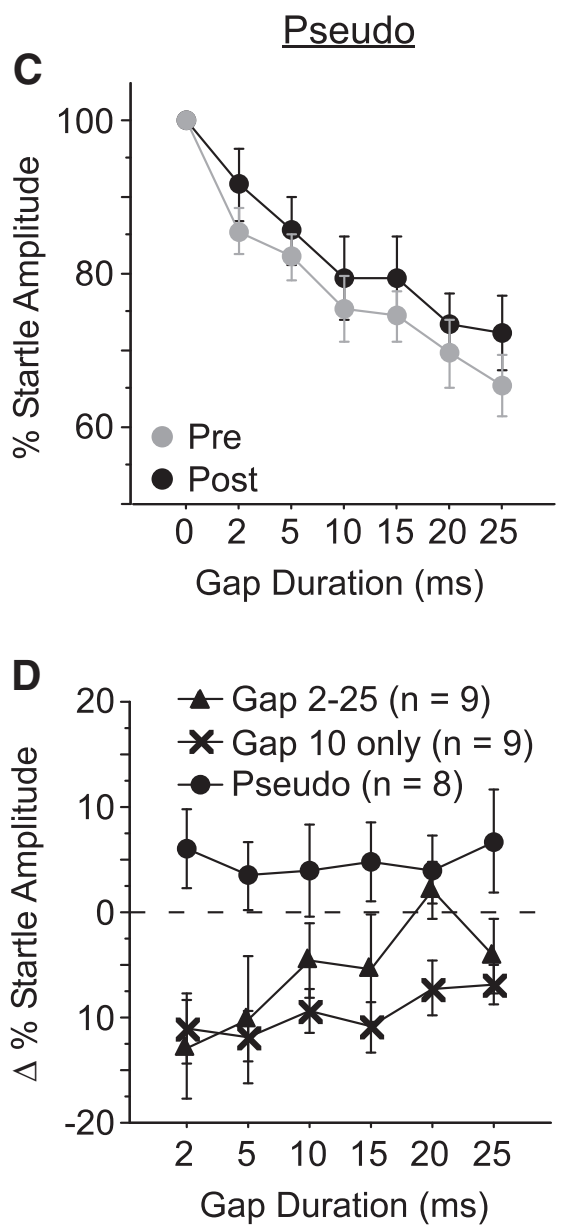

the emotional significance of temporally structured sounds. Auditory cortex is not required for fear conditioning when using a pure tone or white noise CS (LeDoux et al., 1984, LeDoux et al., 1986a, LeDoux et al., 1986b, Romanski and LeDoux, 1992, Campeau and Davis, 1995), but is required with more complex stimuli such as frequency-modulated sweeps (Letzkus et al., 2011). It is still not clear which aspects of stimulus complexity predict the necessity of auditory cortex for fear conditioning (Lindquist and Brown, 2004, Kholodar-Smith et al., 2008). Our findings suggest that temporal structure is a key attribute of this stimulus complexity. Our findings also provide an account for why auditory cortex is necessary for gap detection, even though it is not necessary for many other auditory tasks such as frequency discrimination or PPI (Ison et al., 1991, Threlkeld et al., 2008, Weible et al., 2014). By this account, auditory cortex is critically involved in gap detection and other forms of temporal processing because it serves as a learning pathway for associating meaning with the temporal features of sounds.

Gap detection has been proposed as a model for speech processing, because gaps in noise are analogous to those within and between phonemes in speech (Plomp, 1964). Moreover, gap detection deficits are directly linked to speech perception deficits both in elderly listeners and in children with language learning disorders (Tallal et al., 1985, Glasberg et al., 1987, Schneider et al., 1994, Fitzgibbons and Gordon-Salant, 1996). The fact that auditory cortex is critically involved in fear potentiation of gap detection raises an interesting possibility: the auditory cortical circuitry underlying this associative learning might be a plausible model for as we have shown here, is also required for fear potentiation with 10 ms gaps. However, a previous study reported that auditory cortex is not required for the detection of longer gaps (e.g., 100 ms; Threlkeld et al., 2008). We therefore wondered whether fear potentiation for long gaps would require auditory cortex. To test this, we first established that fear potentiation worked with 100 ms gaps as well as with $10 \mathrm{~ms}$ gaps (Fig. $7 A, n=12$ mice). We then suppressed auditory cortex during $100 \mathrm{~ms}$ gap-shock pairing in a separate group of PV-ChR2 mice $\left(300 \mathrm{~mW} / \mathrm{mm}^{2}\right)$. Suppression abolished fear potentiation for $100 \mathrm{~ms}$ gaps (Fig. $7 D, n=9$ mice), indicating that auditory cortex is required for fear potentiation of long gaps even though it is not required for the detection of those long gaps.

\section{Discussion}

Here, we have demonstrated that auditory cortex is necessary for fear potentiation of gap detection. Pairing a 10 or $100 \mathrm{~ms}$ gap with periorbital shock caused a robust enhancement of gap detection when measured $6 \mathrm{~h}$ later. Optogenetic suppression of auditory cortex during pairing abolished fear potentiation. This indicates that auditory cortex is critically involved in associative learning of speech acquisition-that is, the association of meaning with speech sounds such as phonemes. This would require that learning be stimulus specific. Fear conditioning can be stimulus specific, but can also show stimulus generalization; the relative degree of stimulus specificity and generalization depends on many parameters (Armony et al., 1997, Poremba and Gabriel, 1997, Laxmi et al., 2003, Weinberger, 2004, Bang et al., 2008, Scheich et al., 2011). We found that fear potentiation was not specific for gap duration (Fig. 6). This suggests that the fear potentiation paradigm, at least in its current form, is limited as a model for speech acquisition, especially for how different meanings are learned for temporally distinct phonemes.

Interestingly, even though pseudoconditioned mice that received explicitly unpaired gaps and shocks showed no consistent enhancement of gap detection, they did show mixed changes in gap detection. These changes were significantly more variable across animals compared with mice that were fear conditioned or received only gaps without any shocks, which showed much less variance. This suggests that unpredictable shocks (i.e., those for which mice cannot learn an association) affect variance in gap detection behavior, per- 

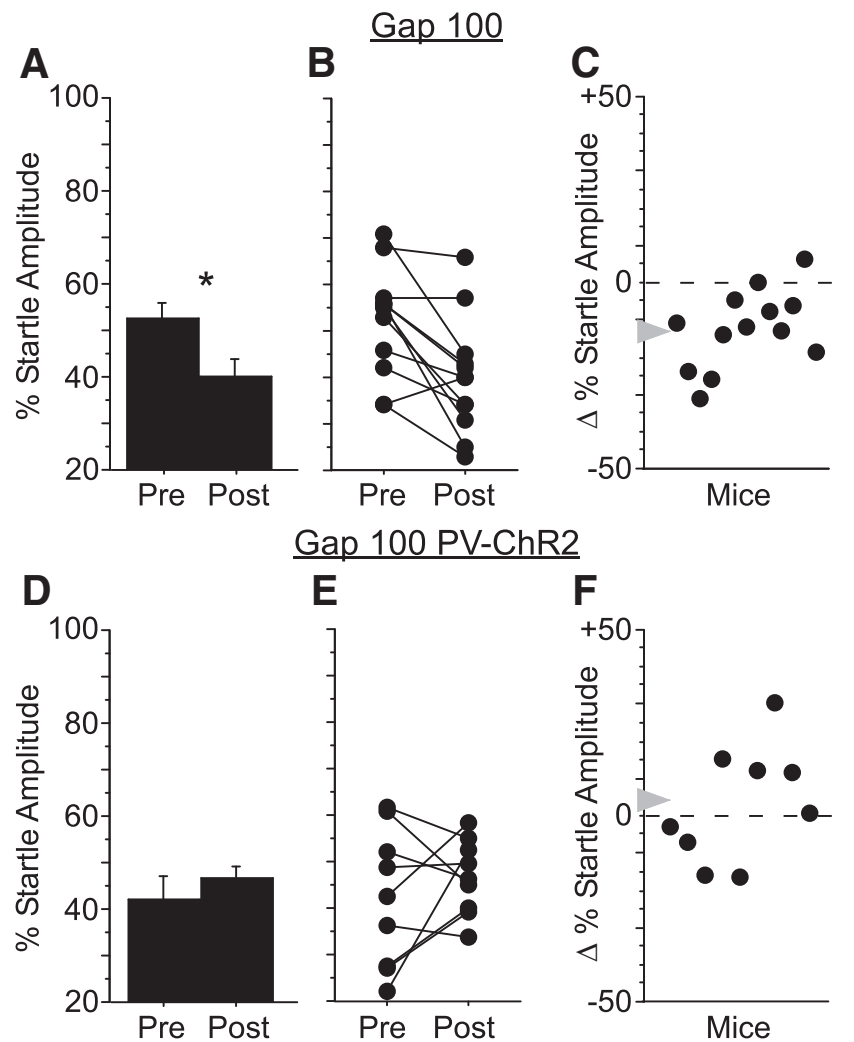

Figure 7. Cortical suppression blocked fear potentiation of $100 \mathrm{~ms}$ gap detection. $A$, Pairing a $100 \mathrm{~ms}$ gap and periorbital shock resulted in a significant increase in startle attenuation by a 100 ms gap (Gap100, $n=11$ ), with consistent increases in gap detection across animals ( $\boldsymbol{B}, \boldsymbol{C}$ ). $D$, Cortical suppression in PV-ChR2 mice blocked learning-related changes in gap detection (Gap100 PV-ChR2, $n=9$ ), with variable changes in behavior across individual animals $(\boldsymbol{E}, \boldsymbol{F})$.

haps by affecting arousal. A similar effect was seen in PV-ChR2 mice with $300 \mathrm{~mW} / \mathrm{mm}^{2}$ suppression, which is consistent with the idea that these mice, like pseudoconditioned mice, could not learn a CS-US association (although this increased variance was not significant in CaMKII-Arch or $200 \mathrm{~mW} / \mathrm{mm}^{2} \mathrm{PV}-\mathrm{ChR} 2$ mice).

Auditory cortex is necessary for the detection of brief gaps (e.g., $10 \mathrm{~ms}$ ), but not for the detection of longer gaps (e.g., 100 $\mathrm{ms})$. However, we found that auditory cortex was necessary for fear potentiation with either 10 or $100 \mathrm{~ms}$ gaps. This raises the question of how auditory cortex can be required for fear potentiation with, but not detection of, $100 \mathrm{~ms}$ gaps. More generally, for which types of stimuli does fear conditioning require auditory cortex? One view is that cortical involvement in fear conditioning depends on stimulus complexity (Ohl et al., 1999, LeDoux, 2000, Kudoh et al., 2006). In this view, gap temporal structure provides enough complexity regardless of gap duration. An alternative view is that auditory cortex is normally involved with auditory fear conditioning for any type of sound. This appears to conflict with the well established finding that auditory cortex is not required for fear conditioning with tones, because lesions of auditory cortex do not prevent fear conditioning. However, auditory cortex exhibits learning-related receptive field plasticity and increased metabolic activity after tone-shock pairings (Bakin and Weinberger, 1990, Poremba et al., 1998) and postconditioning lesions of auditory cortex block recall of recent fear memories (Boatman and Kim, 2006), indicating active cortical involvement during associative fear learning in the intact brain. Successful fear conditioning with pure tones after lesions of auditory cortex, which is known to occur via thalamo-amygdalar projections, might therefore be acting through a compensatory pathway (Romanski and LeDoux, 1992, LeDoux, 2000). Our results therefore join a small but growing body of literature suggesting that temporally precise suppression of neuronal activity is phenomenologically distinct from traditional lesion or inactivation techniques. For example, hippocampal lesions do not block remote recall of contextual fear memory, but deactivating hippocampal neurons precisely at the moment of recruitment does block remote recall (Goshen et al., 2011). Therefore, optogenetic suppression can compromise a functional circuit without engaging compensatory mechanisms that would otherwise obscure ongoing involvement. Indeed, the finding that auditory cortex is not required for the detection of $100 \mathrm{~ms}$ gaps is based on pharmacological inactivation (Threlkeld et al., 2008); it remains unknown whether transient optogenetic suppression of auditory cortex might reveal an involvement in $100 \mathrm{~ms}$ gap detection.

It is important to note that our findings do not demonstrate that auditory cortex is the site of plasticity during fear potentiation of gap detection. Auditory cortex could be critically involved in processing temporal structure but lie upstream of where the plasticity occurs. Nonetheless, our results are consistent with the possibility that the associative plasticity occurs within auditory cortical circuitry, as has been shown to occur for fear conditioning with FM sweeps (Letzkus et al., 2011). How might the gapshock association be formed in auditory cortex? This remains an open question, but a number of recent findings make it tempting to speculate about the cortical circuitry that may be involved. Information about the gap (CS) most likely arrives via thalamocortical inputs to layers 3 and 4 . Gap responses involve an ongoing comparison of activity before and after the gap, which may involve local inhibitory circuits in auditory cortex (Weible et al., 2014). Information about the shock likely arrives via basal forebrain cholinergic projections to layer 1 (L1), including L1 inhibitory interneurons (Mechawar et al., 2000, Letzkus et al., 2011). Acetylcholine has a well established role in auditory cortical plasticity (Suga and Ma, 2003, Ji et al., 2005, Froemke et al., 2007, Weinberger, 2007). Similarly, basal forebrain stimulation induces both auditory cortical plasticity and behavioral memory resembling those seen in learning (McLin et al., 2002, Weinberger, 2007, Bieszczad et al., 2013). These two pathways likely converge at the excitatory-inhibitory network in L2. There, shock-activated $\mathrm{L} 1$ interneurons may inhibit $\mathrm{PV}^{+}$interneurons, thereby disinhibiting pyramidal neurons, as has been shown for conventional fear conditioning (Letzkus et al., 2011). In this scenario, inhibition normally gates the flow of gap information through the circuit, but this gate is opened by cholinergic input during shock pairing. This predicts that gap responses in L2 pyramidal neurons would be enhanced after fear potentiation. Indeed, such enhanced gap responses could be the primary mechanism underlying enhanced behavioral gap detection.

\section{References}

Armony JL, Servan-Schreiber D, Romanski LM, Cohen JD, LeDoux JE (1997) Stimulus generalization of fear responses: effects of auditory cortex lesions in a computational model and in rats. Cereb Cortex 7:157-165. CrossRef Medline

Bakin JS, Weinberger NM (1990) Classical conditioning induces CSspecific receptive field plasticity in the auditory cortex of the guinea pig. Brain Res 536:271-286. CrossRef Medline

Bang SJ, Allen TA, Jones LK, Boguszewski P, Brown TH (2008) Asymmetrical stimulus generalization following differential fear conditioning. Neurobiol Learn Mem 90:200-216. CrossRef Medline

Bieszczad KM, Miasnikov AA, Weinberger NM (2013) Remodeling sensory cortical maps implants specific behavioral memory. Neuroscience 246: 40-51. CrossRef Medline

Boatman JA, Kim JJ (2006) A thalamo-cortico-amygdala pathway mediates audi- 
tory fear conditioning in the intact brain. Eur J Neurosci 24:894-900. CrossRef Medline

Brugge JF, Merzenich MM (1973) Responses of neurons in auditory cortex of the macaque monkey to monaural and binaural stimulation. J Neurophysiol 36:1138-1158. Medline

Campeau S, Davis M (1995) Involvement of subcortical and cortical afferents to the lateral nucleus of the amygdala in fear conditioning measured with fear-potentiated startle in rats trained concurrently with auditory and visual conditioned stimuli. J Neurosci 15:2312-2327. Medline

Eggermont JJ (1999) Neural correlates of gap detection in three auditory cortical fields in the Cat. J Neurophysiol 81:2570-2581. Medline

Engineer CT, Perez CA, Chen YH, Carraway RS, Reed AC, Shetake JA, Jakkamsetti V, Chang KQ, Kilgard MP (2008) Cortical activity patterns predict speech discrimination ability. Nat Neurosci 11:603-608. CrossRef Medline

Fitzgibbons PJ, Gordon-Salant S (1996) Auditory temporal processing in elderly listeners. J Am Acad Audiol 7:183-189. Medline

Froemke RC, Merzenich MM, Schreiner CE (2007) A synaptic memory trace for cortical receptive field plasticity. Nature 450:425-429. CrossRef Medline

Glasberg BR, Moore BC, Bacon SP (1987) Gap detection and masking in hearing-impaired and normal-hearing subjects. J Acoust Soc Am 81: 1546-1556. CrossRef Medline

Goshen I, Brodsky M, Prakash R, Wallace J, Gradinaru V, Ramakrishnan C, Deisseroth K (2011) Dynamics of retrieval strategies for remote memories. Cell 147:678-689. CrossRef Medline

Han X, Chow BY, Zhou H, Klapoetke NC, Chuong A, Rajimehr R, Yang A, Baratta MV, Winkle J, Desimone R, Boyden ES (2011) A high-light sensitivity optical neural silencer: development and application to optogenetic control of nonhuman primate cortex. Front Syst Neurosci 5:18. CrossRef Medline

Ison JR, Pinckney LA (1983) Reflex inhibition in humans: sensitivity to brief silent periods in white noise. Percept Psychophys 34:84-88. CrossRef Medline

Ison JR, O'Connor K, Bowen GP, Bocirnea A (1991) Temporal resolution of gaps in noise by the rat is lost with functional decortication. Behav Neurosci 105:33-40. CrossRef Medline

Issa JB, Haeffele BD, Agarwal A, Bergles DE, Young ED, Yu DT (2014) Multiscale optical CA2 + imaging of tonal organization in mouse auditory cortex. Neuron 83:944-959. CrossRef Medline

Ji W, Suga N, Gao E (2005) Effects of agonists and antagonists of NMDA and ACh receptors on plasticity of bat auditory system elicited by fear conditioning. J Neurophysiol 94:1199-1211. CrossRef Medline

Kholodar-Smith DB, Allen TA, Brown TH (2008) Fear conditioning to discontinuous auditory cues requires perirhinal cortical function. Behav Neurosci 122:1178-1185. CrossRef Medline

Kudoh M, Nakayama Y, Hishida R, Shibuki K (2006) Requirement of the auditory association cortex for discrimination of vowel-like sounds in rats. Neuroreport 17:1761-1766. CrossRef Medline

Laxmi TR, Stork O, Pape HC (2003) Generalisation of conditioned fear and its behavioural expression in mice. Behav Brain Res 145:89-98. CrossRef Medline

LeDoux JE (2000) Emotion circuits in the brain. Annu Rev Neurosci 23: 155-184. CrossRef Medline

LeDoux JE, Sakaguchi A, Reis DJ (1984) Subcortical efferent projections of the medial geniculate nucleus mediate emotional responses conditioned to acoustic stimuli. J Neurosci 4:683-698. Medline

LeDoux JE, Iwata J, Pearl D, Reis DJ (1986a) Disruption of auditory but not visual learning by destruction of intrinsic neurons in the rat medial geniculate body. Brain Res 371:395-399. CrossRef Medline

LeDoux JE, Sakaguchi A, Iwata J, Reis DJ (1986b) Interruption of projections from the medial geniculate body to an archi-neostriatal field disrupts the classical conditioning of emotional responses to acoustic stimuli. Neuroscience 17:615-627. CrossRef Medline

Letzkus JJ, Wolff SB, Meyer EM, Tovote P, Courtin J, Herry C, Lüthi A (2011) A disinhibitory microcircuit for associative fear learning in the auditory cortex. Nature 480:331-335. CrossRef Medline

Li N, Ping J, Wu R, Wang C, Wu X, Li L (2008) Auditory fear conditioning modulates prepulse inhibition in socially reared rats and isolation-reared rats. Behav Neurosci 122:107-118. CrossRef Medline

Lindquist DH, Brown TH (2004) Temporal encoding in fear conditioning revealed through associative reflex facilitation. Behav Neurosci 118:395402. CrossRef Medline

Lisker L, Abramson AS (1964) A cross-language study of voicing in initial stops: acoustical measurements. Word 20:384-422.
McLin DE 3rd, Miasnikov AA, Weinberger NM (2002) Induction of behavioral associative memory by stimulation of the nucleus basalis. Proc Natl Acad Sci U S A 99:4002-4007. CrossRef Medline

Mechawar N, Cozzari C, Descarries L (2000) Cholinergic innervation in adult rat cerebral cortex: a quantitative immunocytochemical description. J Comp Neurol 428:305-318. CrossRef Medline

Moore AK, Wehr M (2013) Parvalbumin-expressing inhibitory interneurons in auditory cortex are well-tuned for frequency. J Neurosci 33: 13713-13723. CrossRef Medline

Ohl FW, Wetzel W, Wagner T, Rech A, Scheich H (1999) Bilateral ablation of auditory cortex in Mongolian gerbil affects discrimination of frequency modulated tones but not of pure tones. Learn Mem 6:347-362. CrossRef Medline

Paxinos G, Franklin KBJ (2001) The mouse brain in stereotaxic coordinates, Ed 2. San Diego: Academic.

Phillips DP, Hall SE, Boehnke SE (2002) Central auditory onset responses, and temporal asymmetries in auditory perception. Hear Res 167:192-205. CrossRef Medline

Plomp R (1964) The rate of decay of auditory sensation. J Acoust Soc Am 36:277-282. CrossRef

Poremba A, Gabriel M (1997) Medial geniculate lesions block amygdalar and cingulothalamic learning-related neuronal activity. J Neurosci 17: 8645-8655. Medline

Poremba A, Jones D, Gonzalez-Lima F (1998) Classical conditioning modifies cytochrome oxidase activity in the auditory system. Eur J Neurosci 10:3035-3043. CrossRef Medline

Romanski LM, LeDoux JE (1992) Equipotentiality of thalamo-amygdala and thalamo-cortico-amygdala circuits in auditory fear conditioning. J Neurosci 12:4501-4509. Medline

Scheich H, Brechmann A, Brosch M, Budinger E, Ohl FW, Selezneva E, Stark H, Tischmeyer W, Wetzel W (2011) Behavioral semantics of learning and crossmodal processing in auditory cortex: the semantic processor concept. Hear Res 271:3-15. CrossRef Medline

Schneider BA, Pichora-Fuller MK, Kowalchuk D, Lamb M (1994) Gap detection and the precedence effect in young and old adults. J Acoust Soc Am 95:980-991. CrossRef Medline

Suga N, MaX (2003) Multiparametric corticofugal modulation and plasticity in the auditory system. Nat Rev Neurosci 4:783-794. CrossRef Medline

Swerdlow NR, Geyer MA, Braff DL (2001) Neural circuit regulation of prepulse inhibition of startle in the rat: current knowledge and future challenges. Psychopharmacology (Berl) 156:194-215. CrossRef Medline

Tallal P, Stark RE, Mellits ED (1985) Identification of language-impaired children on the basis of rapid perception and production skills. Brain Lang 25:314-322. CrossRef Medline

Threlkeld SW, Penley SC, Rosen GD, Fitch RH (2008) Detection of silent gaps in white noise following cortical deactivation in rats. Neuroreport 19:893-898. CrossRef Medline

Walton JP, Frisina RD, Ison JR, O'Neill WE (1997) Neural correlates of behavioral gap detection in the inferior colliculus of the young CBA mouse. J Comp Physiol A 181:161-176. CrossRef Medline

Walton JP, Barsz K, Wilson WW (2008) Sensorineural hearing loss and neural correlates of temporal acuity in the inferior colliculus of the C57BL/6 mouse. J Assoc Res Otolaryngol 9:90-101. CrossRef Medline

Weible AP, Rowland DC, Monaghan CK, Wolfgang NT, Kentros CG (2012) Neural correlates of long-term object memory in the mouse anterior cingulate cortex. J Neurosci 32:5598-5608. CrossRef Medline

Weible AP, Moore AK, Liu C, DeBlander L, Wu H, Kentros C, Wehr M (2014) Perceptual gap detection is mediated by gap termination responses in auditory cortex. Curr Biol 24:1447-1455. CrossRef Medline

Weinberger NM (2004) Specific long-term memory traces in primary auditory cortex. Nat Rev Neurosci 5:279-290. CrossRef Medline

Weinberger NM (2007) Auditory associative memory and representational plasticity in the primary auditory cortex. Hear Res 229:54-68. CrossRef Medline

Zhang J, Laiwalla F, Kim JA, Urabe H, Van Wagenen R, Song YK, Connors BW, Zhang F, Deisseroth K, Nurmikko AV (2009) Integrated device for optical stimulation and spatiotemporal electrical recording of neural activity in lightsensitized brain tissue. J Neural Eng 6:055007. CrossRef Medline

Zou D, Wu X, Li L (2005) Fear conditioning facilitates rats gap detection measured by prepulse inhibition of the startle reflex. J Acoustical Society of America 117. 